\title{
A new estimate of global soil respiration from 1970 to 2008
}

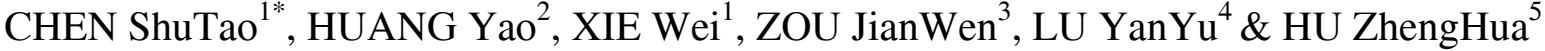 \\ ${ }^{1}$ School of Environmental Science and Engineering, Nanjing University of Information Science and Technology, Nanjing 210044, China; \\ ${ }^{2}$ State Key Laboratory of Vegetation and Environmental Change, Institute of Botany, Chinese Academy of Sciences, Beijing 100093, China; \\ ${ }^{3}$ College of Resources and Environmental Sciences, Nanjing Agricultural University, Nanjing 210095, China; \\ ${ }^{4}$ Anhui Climate Center, Hefei 230031, China; \\ ${ }^{5}$ School of Applied Meteorology, Nanjing University of Information Science and Technology, Nanjing 210044, China
}

Received February 17, 2013; accepted April 24, 2013; published online June 4, 2013

\begin{abstract}
Soil respiration $\left(R_{\mathrm{s}}\right)$ is one of the key processes that underline our understanding of carbon cycle in terrestrial ecosystems. Great uncertainty remains in the previous global $R_{\mathrm{S}}$ estimates with a difference of $70 \mathrm{Pg} \mathrm{C} \mathrm{a}^{-1}$ between the highest and lowest estimates. Thus, the present study aimed to estimate the global annual $R_{\mathrm{s}}$ and investigate the interannual and spatial variability in global annual $R_{\mathrm{s}}$ using a semi-mechanistic, empirically-based model which included climatic factors (temperature and precipitation) and topsoil $(0-20 \mathrm{~cm})$ organic carbon storage. About 657 published studies of annual $R_{\mathrm{S}}$ from 147 measurement sites were included in this meta-analysis. The global data sets from 1970 to 2008 on climate, surface air temperature, and soil properties were collected. The Monte Carlo method was used to propagate the simulation errors to global $R_{\mathrm{s}}$. The results indicated that the mean annual global $R_{\mathrm{s}}$ was $94.4 \mathrm{Pg} \mathrm{C} \mathrm{a}^{-1}$, increasing at roughly $0.04 \mathrm{Pg} \mathrm{C} \mathrm{a}^{-1}\left(\sim 0.04 \% \mathrm{a}^{-1}\right)$ from 1970 to 2008 . The $R_{\mathrm{s}}$ rate increased from colder, drier and less soil carbon-rich regions to warmer, moister and more carbon-rich regions. Highest $R_{\mathrm{s}}$ rates appeared in the tropical forest, while the lowest ones were in polar and desert regions. The annual $R_{\mathrm{S}}$ correlated directly with global temperature anomalies, suggesting that the interannual variability in temperature was responsible for the interannual variations in predicted global $R_{\mathrm{s}}$. The global $R_{\mathrm{s}}$ increased from high-latitude zones to low-latitude zones. Further studies are recommended to explore the relationship between soil respiration and vegetation characters.
\end{abstract}

soil respiration, global, latitude, temperature, precipitation

Citation: $\quad$ Chen S T, Huang Y, Xie W, et al. A new estimate of global soil respiration from 1970 to 2008. Chin Sci Bull, 2013, 58: 4153-4160, doi: 10.1007/s11434-013-5912-1

Terrestrial carbon cycle plays an important role in the atmospheric carbon dioxide $\left(\mathrm{CO}_{2}\right)$ budget. Soil respiration $\left(R_{\mathrm{S}}\right)$ represents the second largest carbon flux between ecosystems and the atmosphere [1]. Approximately $10 \%$ of the atmospheric $\mathrm{CO}_{2}$ cycles through terrestrial soil each year [2]. The budget of autotrophic and heterotrophic components of $R_{\mathrm{s}}$ can significantly mitigate or intensify the current $\mathrm{CO}_{2}$ increases in the atmosphere. $R_{\mathrm{s}}$, therefore, is one of the key processes that underline our understanding of carbon cycle in terrestrial ecosystems [3]. Environmental changes that can alter the terrestrial soil $\mathrm{CO}_{2}$ emissions might have a potential to affect the atmospheric $\mathrm{CO}_{2}$ concentration [2].

*Corresponding author (email: chenstyf@yahoo.com.cn)
Because of the global significance as well as considerable scientific commitment to the study of $R_{\mathrm{s}}$ [1], the number of investigations for modeling $R_{\mathrm{S}}$ has increased rapidly over the last decades $[1,4-7]$. However, there is still great uncertainty of global $R_{\mathrm{s}}$ estimates [1]. Estimated global $R_{\mathrm{s}}$ varied from 50 to $120 \mathrm{Pg} \mathrm{C} \mathrm{a}^{-1}$ with a great difference of $70 \mathrm{Pg} \mathrm{C} \mathrm{a}^{-1}$ between the highest and lowest estimates [2,6-12]. This uncertainty greatly restricts the understanding of terrestrial carbon cycle. Moreover, the interannual variability and latitudinal distribution of global $R_{\mathrm{S}}$ have not been well known [2], although such information might provide implications for global patterns of carbon source or sink [13-15].

Temperature and precipitation have strong impacts on soil respiration rates. A great deal of work has been done on 
how soils might (or might not) lose carbon with changing climate [16-18]. Temperature is commonly believed to be the most important climatic factor driving $R_{\mathrm{s}}$, which has been reviewed by a number of studies [10,19-21]. A positive feedback between the terrestrial $R_{\mathrm{s}}$ and global warming is supposed to arise [7,22-24]. The soil moisture availability is related to precipitation with dry soils producing less $\mathrm{CO}_{2}$ than wet soils $[2,25]$. The soil $\mathrm{CO}_{2}$ emissions are also controlled by topsoil $(0-20 \mathrm{~cm})$ organic carbon (SOC) storage. The SOC-rich soils generally produce more $\mathrm{CO}_{2}[21,26-$ 28 ]. Overall, the global $R_{\mathrm{s}}$ could be largely modeled by annual mean temperature, annual total precipitation, and sitespecific SOC storage [29]. In the previous study, a new semi-empirical model (T\&P\&C-model) was established including annual air temperature, annual precipitation, and 0-20 cm SOC storage [29]. The T\&P\&C-model have several benefits compared with several previous investigations $[2,6]$. For instance, Raich et al. [2] used only the climate variables (temperature and precipitation) as predictors. However, our model included both climate and soil variables as predictors. Bond-Lamberty and Thomson [6] used linear model to fit global $R_{\mathrm{s}}$, but the proposed model involved a semi-empirical one including a classic exponent and Michaelis-Menten functions rather than the purely arithmetical fitting.

Thus, the present study aimed to estimate the global annual $R_{\mathrm{s}}$ and investigate the interannual and spatial variability in global annual $R_{\mathrm{s}}$ using a semi-mechanistic, empirically-based model which included climatic factors (temperature and precipitation) and SOC storage. Given the great uncertainty in previous global $R_{\mathrm{s}}$ estimates, the amount of global annual $R_{\mathrm{s}}$ were also re-estimaed. The study also aimed to investigate the kind of patterns that the global $R_{\mathrm{s}}$ showed within different latitude zones in the past $\sim 40$ years. The Monte Carlo method was used to propagate the simulation errors to global $R_{\mathrm{s}}$ and compute standard error.

\section{Methodology}

The interannual variability and spatial distribution of $R_{\mathrm{s}}$ was investigated following the semi-mechanistic modeling method of Chen et al. [29]. The process-based terrestrial carbon cycle models could predict $\mathrm{CO}_{2}$ produced separately by soil microbes (heterotrophic components) and roots (autotrophic components), neither of which could involve direct measurement in field intact soils. In contrast to that, the model used in the present study involved three variables and four parameters, which directly could predict a widelymeasured single $R_{\mathrm{S}}$ [2]. The model is actually based on the meta-data analysis of the true data sets of annual $R_{\mathrm{s}}$. In contrast to the models of Bond-Lamberty and Thomson [6,7] which included the extrapolation of annual $R_{\mathrm{s}}$ from seasonal (from 4 to 9 months) measurements or obtained using measurements with low frequency, the present study in- volved only the annual $R_{\mathrm{S}}$ measurements reported in the literatures. About 657 published studies of annual $R_{\mathrm{S}}$ from 147 measurement sites were included in the study. These sites were distributed from $37^{\circ} 31^{\prime} \mathrm{S}$ to $78^{\circ} 00^{\prime} \mathrm{N}$ latitude and from $155^{\circ} 07^{\prime} \mathrm{W}$ to $149^{\circ} 10^{\prime} \mathrm{E}$ longitude, covering most of the biome types and climate zones globally. The ecosystemspecific $R_{\mathrm{S}}$ values for the following proportion of the 657 measurements were derived: $R_{\mathrm{S}}$ in croplands, $10.9 \% ; R_{\mathrm{S}}$ in grasslands, $17.2 \% ; R_{\mathrm{s}}$ in forests, $70.8 \%$; and $R_{\mathrm{s}}$ in tundras, $1.1 \%$ [29]. The annual total precipitation, annual mean air temperature, and SOC were also determined. The data sets from the 1980s to the 2000s (Figure 1) included the measured annual $R_{\mathrm{S}}$ from China and other countries, covering the most terrestrial ecosystem types across the world. Approximately, $88 \%$ of the annual $R_{\mathrm{s}}$ rates were within the range of $0.1-1.5 \mathrm{~kg} \mathrm{C} \mathrm{m}^{-2} \mathrm{a}^{-1}$. For the data sets, there were 97 annual $R_{\mathrm{s}}$ samples measured in China, occupying $20.5 \%$ of the global data sets. Approximately, $85 \%$ global $R_{\mathrm{s}}$ data (mainly from United States of America, Europe, and China) were measured within the lattitude range of $20^{\circ}-60^{\circ} \mathrm{N}$. To describe the dependence of the annual $R_{\mathrm{S}}$ on temperature $\left(T,{ }^{\circ} \mathrm{C}\right)$, precipitation $(P, \mathrm{~m})$, and SOC storage $\left(\mathrm{kg} \mathrm{C} \mathrm{m}^{-2}\right)$, a $\mathrm{T} \& \mathrm{P} \& \mathrm{C}$-model was established using these three drivers.

These factors acted as predictors for $R_{\mathrm{s}}\left(\mathrm{kg} \mathrm{C} \mathrm{m}^{-2} \mathrm{a}^{-1}\right)$ to simulate annual $R_{\mathrm{s}}$ [29] per the following equation:

$$
R_{\mathrm{s}}=R_{0} \mathrm{e}^{Q T} \cdot \frac{P}{P+K} \cdot \frac{\mathrm{SOC}}{\mathrm{SOC}+M},
$$

where $Q\left({ }^{\circ} \mathrm{C}^{-1}\right)$, temperature sensitivity coefficient, determines the relationship between $R_{\mathrm{s}}$ and temperature, $K(\mathrm{~m})$ represents the half-saturation constant of the hyperbolic Michaelis-Menten relationship of $R_{\mathrm{s}}$ with annual precipitation, and $M\left(\mathrm{~kg} \mathrm{C} \mathrm{m}^{-2}\right)$ represents the half-saturation constant of the Michaelis-Menten relationship of $R_{\mathrm{S}}$ with SOC storage.

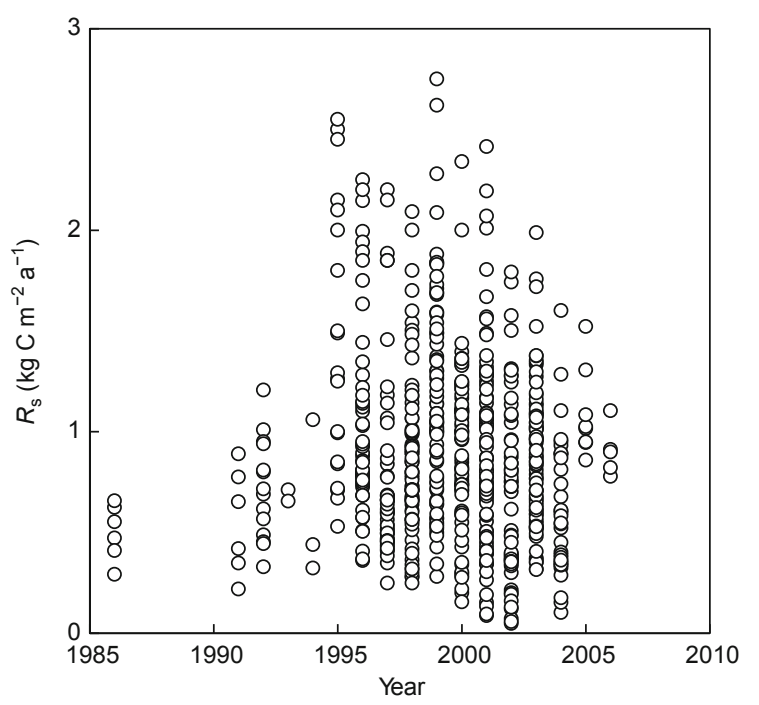

Figure 1 Published annual soil respiration $\left(R_{\mathrm{s}}\right)$ measurements from the 1980 s to the 2000 s. 
The model was established and validated by using a $k$-fold cross-validation method. The whole data sets were randomly partitioned into roughly equal subsamples (folds, $k=6$ ). The $k-1$ folds were called as training set, while the excluded fold was called validation set. The model was fitted against training set, and the validation set was used for model validation. For the cross-validation process, each fold was used successively as a validation subset [29-31]. The model was parameterized by calculating a nonlinear least squares fit of the parameters $\left(R_{0}, Q, K\right.$, and $\left.M\right)$ to the data sets, and the parameters were driven by climate data (temperature and precipitation) and $0-20 \mathrm{~cm}$ SOC storage. The fitting process optimized the model parameters to make the model fit the training data as much as possible. The $k$ results from the folds were then combined to produce a single estimation. To reduce the variability, multiple rounds of crossvalidation were performed using different folds, and the parameters $\left(R_{0}, Q, K\right.$, and $\left.M\right)$ and validation results were averaged over the 6 rounds. The following statistical considerations were used for the model evaluation: root mean squared error (RMSE), coefficient of determination $\left(R^{2}\right)$, and modeling efficiency (MEF) [32]. Detailed information about the data sets and model evaluation can be found in our previous work [29]. The parameterized model was

$$
R_{\mathrm{s}}=1.55 \mathrm{e}^{0.031 T} \cdot \frac{P}{P+0.68} \cdot \frac{\mathrm{SOC}}{\mathrm{SOC}+2.23} .
$$

The global $R_{\mathrm{S}}$ was estimated applying the fitted model derived by the geographical grid cell, climate data, and soil properties. The global climate data sets (1970-2008) were obtained from the website of Center for Climatic Research, University of Delaware (http://climate.geog.udel.edu/ climate). The global surface air temperature anomalies data sets were downloaded from the website of Goddard Institute for Space Studies of NASA (http://data.giss.nasa.gov/ gistemp). The term "temperature anomaly" means a departure from a reference temperature or long-term averaged value [33]. The reference value used was the 1951-1980 global mean surface air temperature $\left(14^{\circ} \mathrm{C}\right)$ [33]. The data sets of global soil properties [34,35] were obtained from the website of International Soil Reference and Information Centre-World Soil Information (http://www.isric.org). All data sets were analyzed at the resolution of $0.5^{\circ} \times 0.5^{\circ}$ during geographical grid cell analysis.

The Monte Carlo method was used to propagate the simulation errors to global $R_{\mathrm{s}}$. For each trial $(N=300$ in total), a new randomized model was generated on the basis of the estimate and standard error for each parameter $\left(R_{0}, Q\right.$, $K$, and $M$ ) in the original T\&P\&C-model. This new model was used to calculate the annual global $R_{\mathrm{s}}$ for each year from 1970 to 2008. All random models were then used to generate the final data sets for computing standard error of global $R_{\mathrm{s}}$.

\section{Results and discussions}

From the study results, spatial patterns were clearly observed in the global $R_{\mathrm{s}}$. Temperature, precipitation, and SOC could interact to impose complicated and varying limitations on $R_{\mathrm{s}}$ in different regions of the terrestrial ecosystem. Highest $R_{\mathrm{s}}$ rates were found in the tropical forest, while the lowest ones appeared in polar and desert regions (Figure 2 ). Overall, $R_{\mathrm{S}}$ rate increases from the colder, drier, and less soil carbon-rich regions to warmer, moister, and more carbon-rich regions.

The estimated mean global annual $R_{\mathrm{s}}$ from 1970 to 2008 was 94.4 $\mathrm{Pg} \mathrm{C} \mathrm{a}^{-1}$. From 1970 to 2008 , the global annual $R_{\mathrm{S}}$ was estimated to range from 91.3 to $96.8 \mathrm{Pg} \mathrm{C} \mathrm{a}^{-1}$ (Table 1), with the highest and lowest $R_{\mathrm{s}}$ rates in 1972 and 1998, respectively (Figure 3(a)). The lowest and highest $R_{\mathrm{s}}$ rates in 1972 and 1998 were corresponded to strong La Niña (19971998) and El Niño (1971-1972) events, respectively. Previous global $R_{\mathrm{s}}$ estimates varied from 50.0 to $120.0 \mathrm{Pg} \mathrm{C} \mathrm{a}^{-1}$ with a great difference of $70.0 \mathrm{Pg} \mathrm{C} \mathrm{a}{ }^{-1}$ between the highest and lowest estimates (Table 1). The estimation of global $R_{\mathrm{s}}$ in the present study was comparable to Bond-Lamberty and Thomson [6,7], who estimated that the global annual $R_{\mathrm{s}}$ in 2008 was $98.0 \pm 12.0 \mathrm{Pg} \mathrm{C}$, which was $1.2 \%-2.9 \%$ higher than the present study estimates (Table 1).

A significant increasing tendency of global $R_{\mathrm{s}}$ could be found from 1970 to 2008 (Figure 3(a)). During this period, global $R_{\mathrm{s}}$ was significantly $(P=0.039)$ increasing at $\sim 0.04$ $\mathrm{Pg} \mathrm{C} \mathrm{a}{ }^{-1}\left(0.04 \% \mathrm{a}^{-1}\right)$. However, no significant increase $(P>0.1)$ in global annual $R_{\mathrm{S}}$ was found from 1989 to 2008 , which was different with a recent estimate using a similar meta-analysis method [6]. Bond-Lamberty and Thomson [6] pointed out that annual global $R_{\mathrm{s}}$ varied from 94 to 98 $\mathrm{Pg} \mathrm{C} \mathrm{a}{ }^{-1}$ from 1960 to 2008 (Table 1) and increased at 0.1 $\mathrm{Pg} \mathrm{C} \mathrm{a}^{-1}\left(0.1 \% \mathrm{a}^{-1}\right)$ particularly from 1989 to 2008 . However, the estimates showed that the increasing global $R_{\mathrm{s}}$ was accompanied by the increasing global temperature anomalies (Figure 3(b)), which was similar with the results from Bond-Lamberty and Thomson [6].

There were several advantages for the present model compared with the recent studies by Bond-Lamberty and Thomson [6,7]. First, the data sets strictly focused on the annual $R_{\mathrm{s}}$ measurements rather than seasonal measurements [29], while the seasonal $R_{\mathrm{s}}$ measurements were included in the meta-analysis by Bond-Lamberty and Thomson [6,7]. Even short-term measurements (i.e. $R_{\mathrm{s}}$ measurements made over less than 2 weeks) were entered into the meta-analysis if the authors extrapolated their results to seasonal or annual values. More than $20 \%$ annual $R_{\mathrm{s}}$ effluxes which BondLamberty and Thomson [6,7] compiled to model global $R_{\mathrm{s}}$ were extrapolated from the growing season or short-term measurements. As $R_{\mathrm{S}}$ effluxes for the growing season are generally higher than those for non-growing season, the compiled $R_{\mathrm{s}}$ data sets used by Bond-Lamberty and Thomson $[6,7]$ might result in greater annual $R_{\mathrm{s}}$ estimates accompanied 

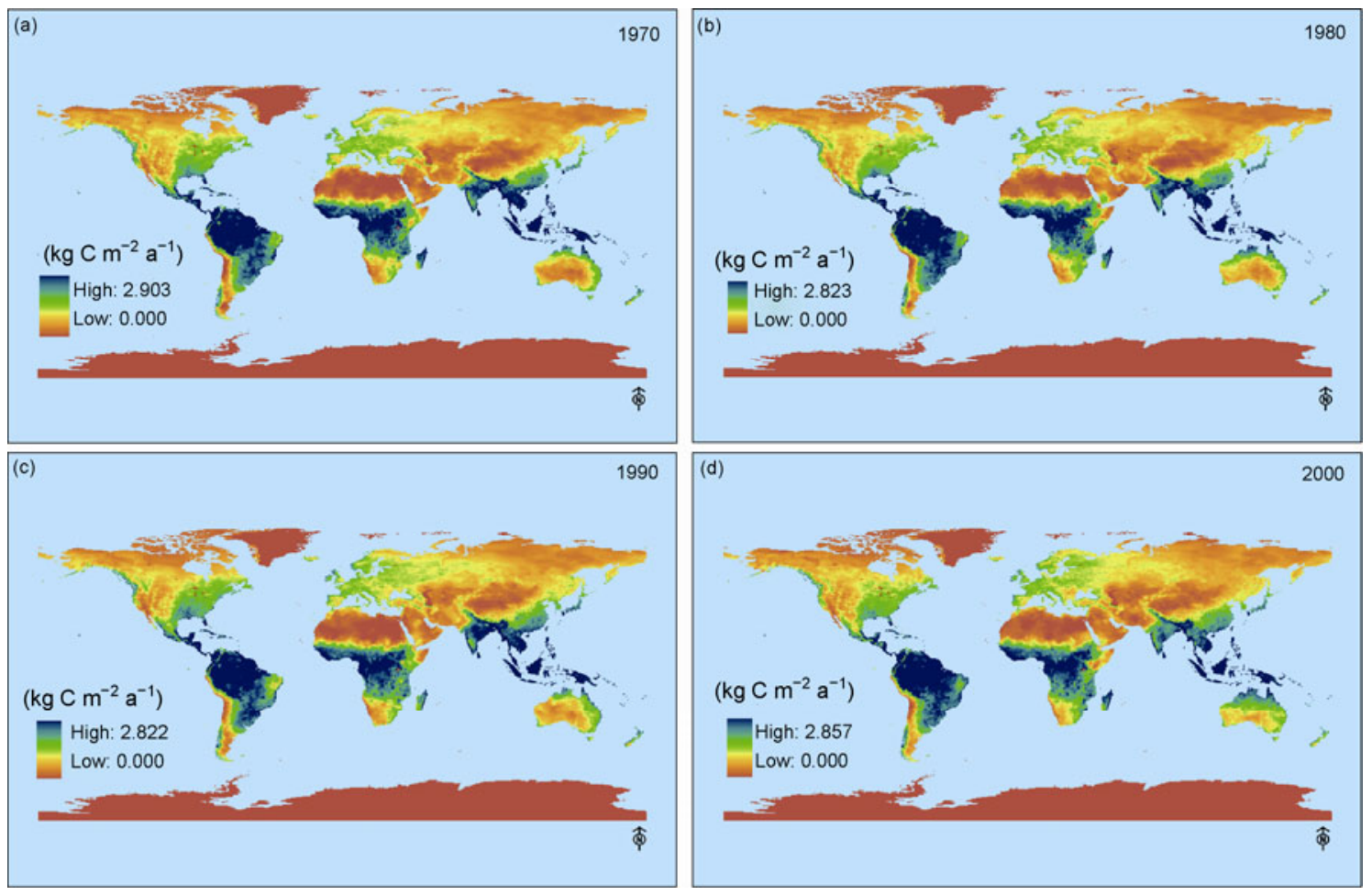

Figure 2 Global distribution of annual $R_{\mathrm{s}}$.

Table 1 Comparison of estimated global $R_{\mathrm{s}}$ or $R_{\mathrm{s}} \pm$ standard error

\begin{tabular}{lcc}
\hline \multicolumn{1}{c}{ Period $^{\text {a) }}$} & $R_{\mathrm{s}}(\operatorname{Pg} \mathrm{C})$ & Reference \\
\hline NA & 50.0 & {$[9]$} \\
NA & 75.0 & {$[8]$} \\
NA & 68.0 & {$[10]$} \\
NA & $76.5-79.1$ & {$[11]$} \\
NA & 120.0 & {$[12]$} \\
$1980-1994$ & $79.3-81.0$ & {$[2]$} \\
$1960-2008$ & $94.0 \pm 12.0-98.0 \pm 12.0$ & {$[6,7]$} \\
$1970-2008$ & $91.3 \pm 8.7-96.8 \pm 9.2$ & This study \\
\hline
\end{tabular}

a) NA, not available.

by the prediction of annual $R_{\mathrm{S}}$ from seasonal measurement across various biomes. Second, our semi-empirical model was based on the classic exponent and Michaelis-Menten relationship functions. Bond-Lamberty and Thomson [6] used pure linear models to examine the effects of climate, biophysical variables, and year of measurement; all which limited explaining the mechanism on how environmental factors affected the global $R_{\mathrm{s}}$. Thirdly, when $R^{2}$ was considered, our model $\left(R^{2}=0.600\right)$ performed better than each of the 4 models ( $R^{2}$ varied from 0.320 to 0.426 ) established by Bond-Lamberty and Thomson [6]. For instance, one of their model $\left(R^{2}=0.426\right)$ including temperature, precipitation, nitrogen deposition, and leaf as indices had $302 R_{\mathrm{S}}$ measurements; while the model in the present study included $657 R_{\mathrm{s}}$ measurements. Moreover, two key statistics of RMSE and
MEF were not employed by Bond-Lamberty and Thomson [6] to evaluate the model, while the present study model employed them and resulted in relatively small RMSE value $\left(0.33 \mathrm{~kg} \mathrm{C} \mathrm{m}^{-2} \mathrm{a}^{-1}\right)$ and high MEF (0.59). Fourthly, the standard error calculated by the Monte Carlo method in the present study was less than that reported by Bond-Lamberty and Thomson [6], although the number $(N=300)$ of repeated trials in this study was less than that $(N=1000)$ in their study [6].

Overall, the data sets used to model the global $R_{\mathrm{s}}$ provided a solid foundation to obtain a reasonable global $R_{\mathrm{s}}$ estimate, and the model used in the present study performed better than the recent linear model proposed by BondLamberty and Thomson [6] with the statistics of $R^{2}$, number of samples, RMSE, MEF, and standard error were comprehensively considered. Given the general contribution of heterotrophic respiration to total $R_{\mathrm{S}}$ [36], the estimated global heterotrophic respiration rates ranged from 51.2 to 53.4 $\mathrm{Pg} \mathrm{C} \mathrm{a}{ }^{-1}$, which were also consistent with a previous estimation of global heterotrophic respiration [37] and were comparable to the global NPP estimates [38,39].

When the spatial patterns were considered, the global $R_{\mathrm{s}}$ showed clear latitudinal distribution patterns (Figure 4). In each latitude zone, as shown in Figure 4, the regional $R_{\mathrm{s}}$ was calculated as the arithmetic average of all gridded estimates in this latitude zone. The $R_{\mathrm{S}}$ increased from high-latitude zones to low-latitude zones. The global $R_{\mathrm{S}}$ showed a significant increasing tendency between 1970 and 2008, which was particularly attributed to the increase of $R_{\mathrm{S}}$ in high- 


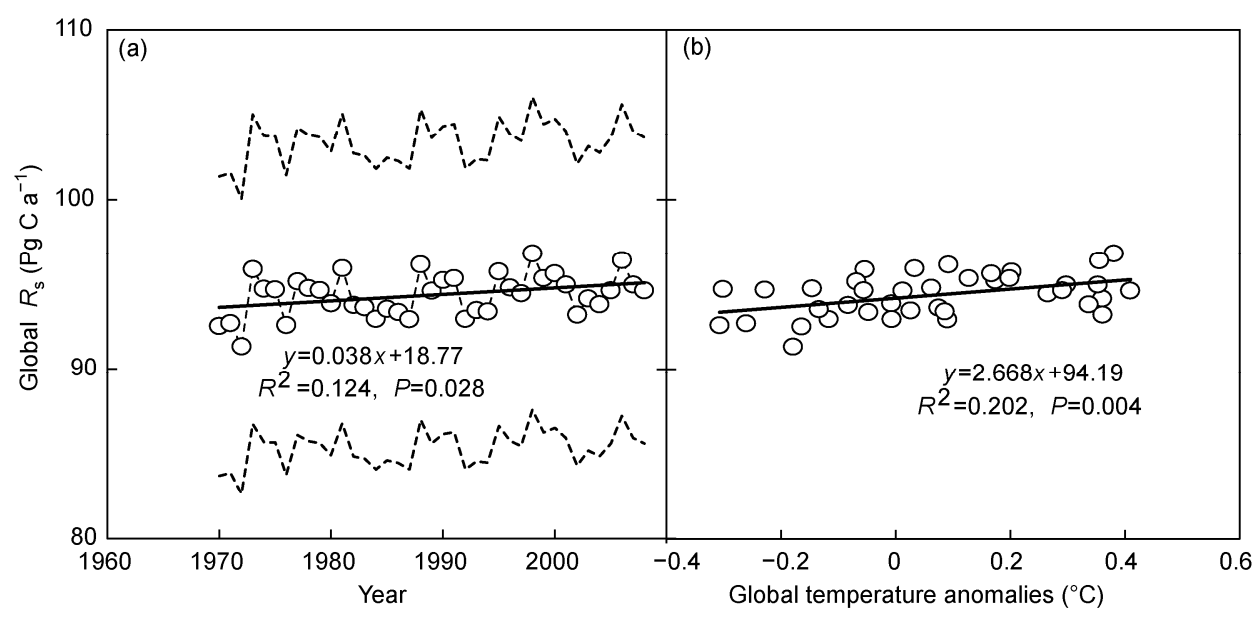

Figure 3 Interannual variability of global $R_{\mathrm{s}}$ from 1970 to 2008 and relationship between global $R_{\mathrm{s}}$ and temperature anomalies during this time period. The dashed lines show the standard errors of the Monte Carlo simulations $(N=300)$.

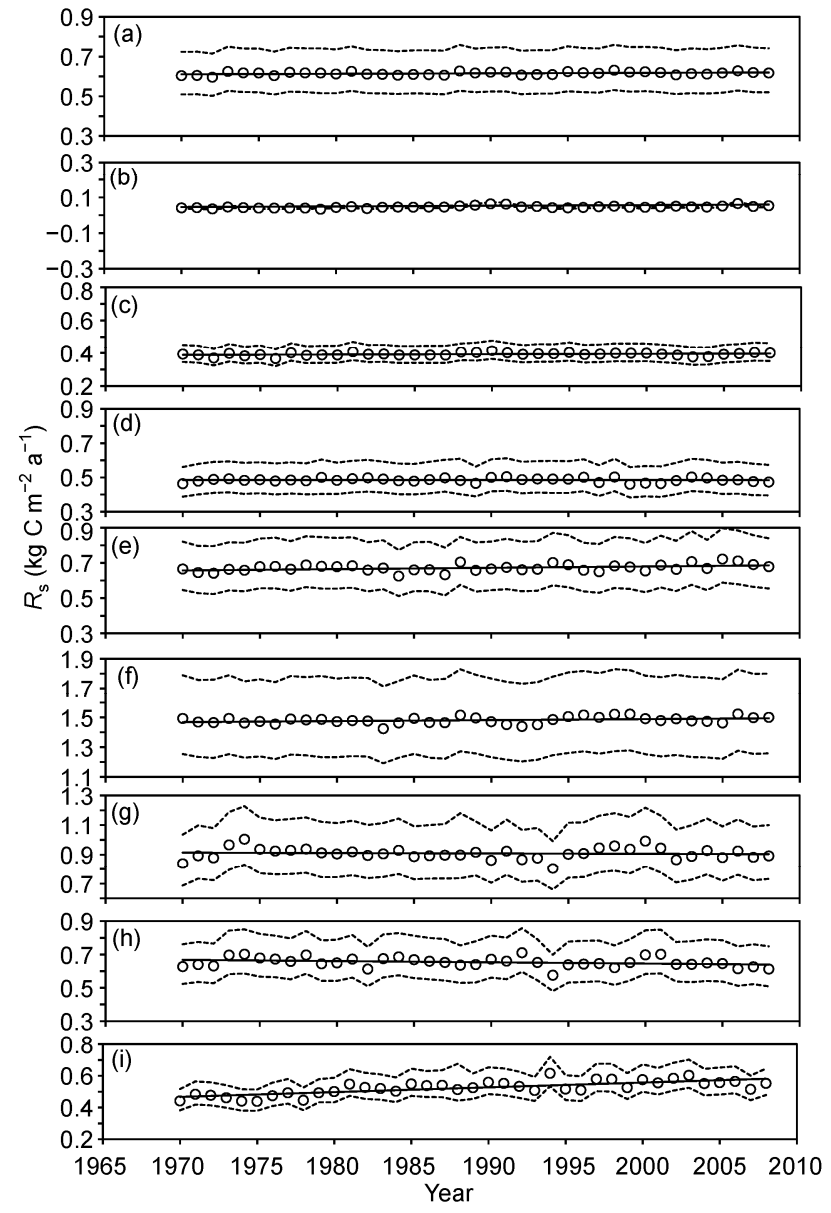

Figure 4 Temporal variability in $R_{\mathrm{s}}$ within each of the latitude zones. (a)-(i) represent the global, $90^{\circ}-75^{\circ} \mathrm{N}, 75^{\circ}-45^{\circ} \mathrm{N}, 45^{\circ}-30^{\circ} \mathrm{N}, 30^{\circ}-10^{\circ} \mathrm{N}$, $10^{\circ} \mathrm{N}-10^{\circ} \mathrm{S}, 10^{\circ}-30^{\circ} \mathrm{S}, 30^{\circ}-45^{\circ} \mathrm{S}$, and $45^{\circ}-60^{\circ} \mathrm{S}$ latitude zones, respectively. In each latitude zone, the regional $R_{\mathrm{s}}$ was calculated as the arithmetic average. The global $R_{\mathrm{S}}$ showed a significant increasing tendency between 1970 and 2008, particularly within the latitude zones from $75^{\circ}$ and $90^{\circ} \mathrm{N}$ and from $45^{\circ}$ to $60^{\circ} \mathrm{S}$. The cycles represent the estimated mean $R_{\mathrm{s}}$ within each latitude zone; and the dashed lines are $95 \%$ confidential intervals. The solid thin lines represent regression line. The functions for the regression lines are shown in Table 2. latitude regions (from $75^{\circ}$ to $90^{\circ} \mathrm{N}$ and from $45^{\circ}$ to $60^{\circ} \mathrm{S}$ ) and tropical zones (Table 2). The $R_{\mathrm{s}}$ rates in the latitude zone of $45^{\circ}-60^{\circ} \mathrm{S}$ were increasing at $0.3 \%$ per year from 1970 to 2008. A significant $\left(R^{2}=0.115, P=0.034\right)$ increase in $R_{\mathrm{S}}$ was also found over years from $10^{\circ} \mathrm{N}$ to $10^{\circ} \mathrm{S}$. However, $R_{\mathrm{s}}$ within $30^{\circ}-75^{\circ} \mathrm{N}$ and $10^{\circ}-45^{\circ} \mathrm{S}$ showed no significant change over this time period (Figure 4 and Table 2). Specifically, annual $R_{\mathrm{s}}$ rate in subtropical zones such as southern Asia and southern China was higher in 1970 than that in 2000. The different temporal patterns of temperature and precipitation within different latitude zones might drive the temporal and latitudinal variability in $R_{\mathrm{s}}$. When the temporal variability in mean annual precipitation within each latitude zone was considered, the mean annual precipitation increased significantly only within the latitude zone of $45^{\circ}-60^{\circ} \mathrm{S}$ (Figure 5). As shown in Figure 6, the mean annual temperature increased significantly over the years within each latitude zone. In the northern hemisphere, the increasing rates of mean annual temperature were greater in the higher latitude zones, particularly from $75^{\circ}$ to $90^{\circ} \mathrm{N}$. In tropical zones (from $10^{\circ} \mathrm{N}$ to $10^{\circ} \mathrm{S}$ ), the mean annual temperature increased significantly during the time period of 1970-2008, while the mean annual precipitation showed no such significant increase. Furthermore, the numerous studies had demonstrated the mid-latitude increases in NPP based on the combinations of in situ observations, terrestrial biosphere models, and satellite remote sensing [39-42]. Combining the results from the NPP increase, the stable $R_{\mathrm{s}}$ across the mid-latitude zones might partly explain the reported terrestrial carbon sink in these regions [42-45].

Further investigations about global soil respiration simulation should focus on the relationship between soil respiration and vegetation characters. More in situ measurements of the soil respiration and relevant environmental controls including climatic factors (e.g. temperature and precipitation), vegetation characters (e.g. LAI, root biomass), 


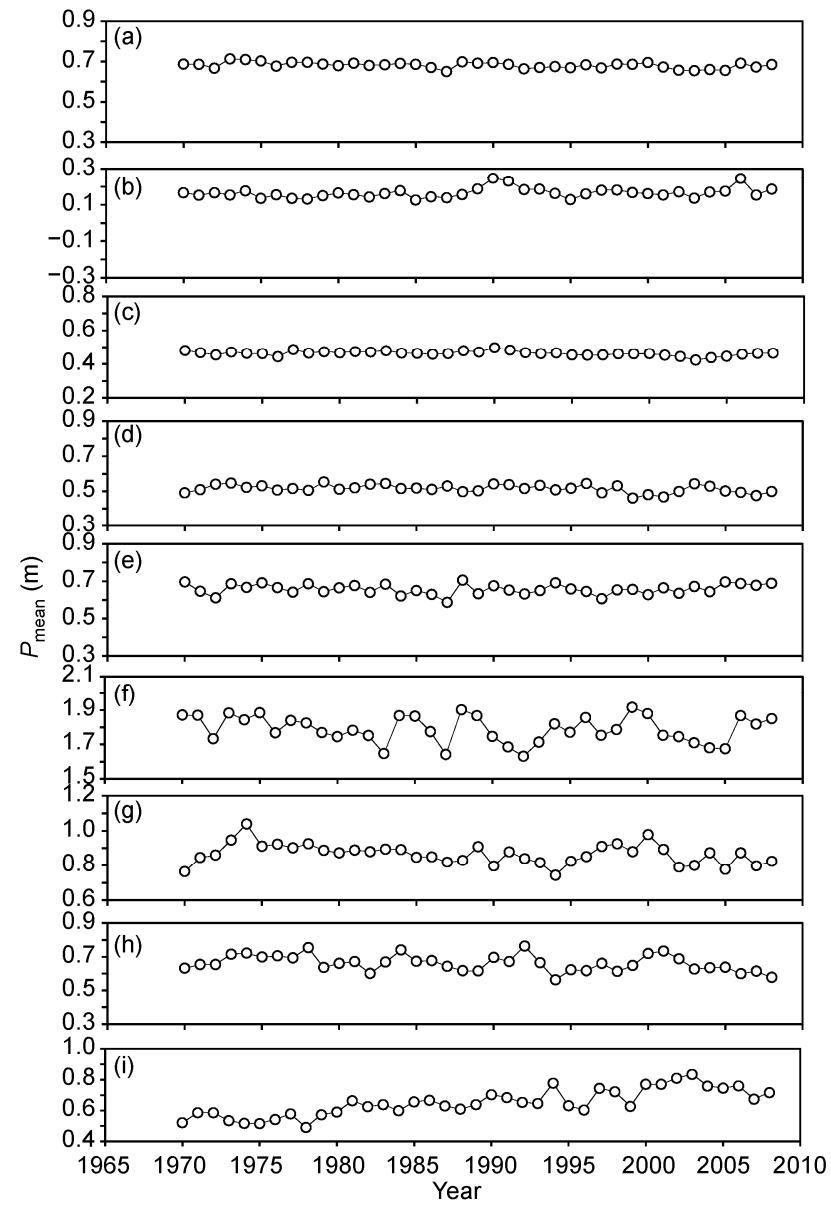

Figure 5 Temporal variability in mean annual precipitation $\left(P_{\text {mean }}\right)$ within each of the latitude zones. (a)-(i) represent the global, $90^{\circ}-75^{\circ} \mathrm{N}, 75^{\circ}-$ $45^{\circ} \mathrm{N}, 45^{\circ}-30^{\circ} \mathrm{N}, 30^{\circ}-10^{\circ} \mathrm{N}, 10^{\circ} \mathrm{N}-10^{\circ} \mathrm{S}, 10^{\circ}-30^{\circ} \mathrm{S}, 30^{\circ}-45^{\circ} \mathrm{S}$, and $45^{\circ}-$ $60^{\circ} \mathrm{S}$ latitude zones, respectively. In each latitude zone, the regional mean annual precipitation was calculated as the arithmetic average. The maximum precipitation and minimum precipitation are indicated in Figures S1 and $\mathrm{S} 2$, respectively.

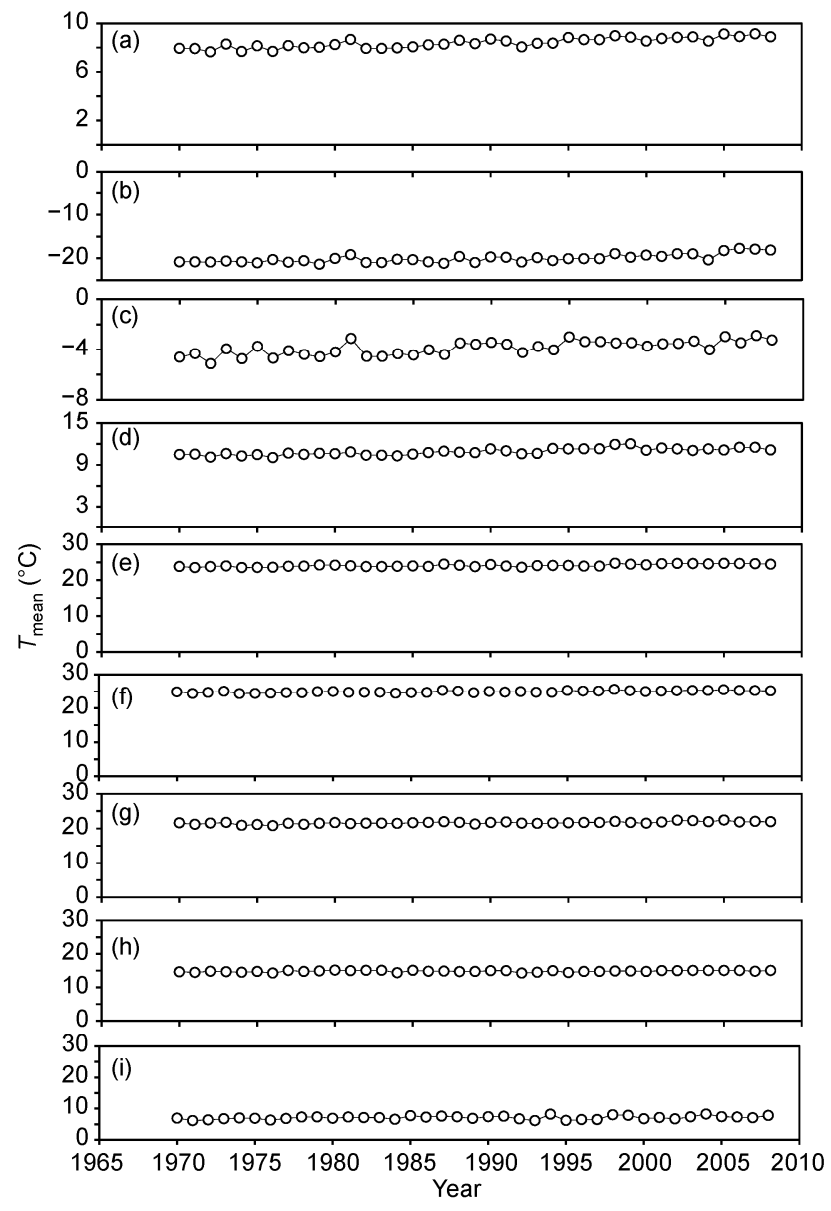

Figure 6 Temporal variability in mean annual temperature $\left(T_{\text {mean }}\right)$ within each of the latitude zones. (a)-(i) represent the global, $90^{\circ}-75^{\circ} \mathrm{N}, 75^{\circ}-$ $45^{\circ} \mathrm{N}, 45^{\circ}-30^{\circ} \mathrm{N}, 30^{\circ}-10^{\circ} \mathrm{N}, 10^{\circ} \mathrm{N}-10^{\circ} \mathrm{S}, 10^{\circ}-30^{\circ} \mathrm{S}, 30^{\circ}-45^{\circ} \mathrm{S}$, and $45^{\circ}-$ $60^{\circ} \mathrm{S}$ latitude zones, respectively. In each latitude zone, the regional mean annual temperature was calculated as the arithmetic average. The maximum temperature and minimum temperature are indicated in Figures S3 and $\mathrm{S} 4$, respectively.

Table 2 Functions for the regression lines explaining the trends of mean $R_{\mathrm{s}}\left(\mathrm{kg} \mathrm{C} \mathrm{m}^{-2} \mathrm{a}^{-1}\right)$ for each latitude zone from 1970 to $2008^{\mathrm{a}}$

\begin{tabular}{rllc}
\hline Latitude zone & \multicolumn{1}{c}{ Function } & $R^{2}$ & $P$ \\
\hline $90^{\circ}-75^{\circ} \mathrm{N}$ & $y=0.0003 x-0.587$ & 0.27 & 0.001 \\
$75^{\circ}-45^{\circ} \mathrm{N}$ & $y=0.0002 x-0.058$ & 0.07 & 0.117 \\
$45^{\circ}-30^{\circ} \mathrm{N}$ & $y=-0.00005 x+0.58$ & 0.00 & 0.798 \\
$30^{\circ}-10^{\circ} \mathrm{N}$ & $y=0.0008 x-0.828$ & 0.17 & 0.010 \\
$10^{\circ} \mathrm{N}-10^{\circ} \mathrm{S}$ & $y=0.0007 x+0.129$ & 0.12 & 0.034 \\
$10^{\circ}-30^{\circ} \mathrm{S}$ & $y=-0.0003 x+1.433$ & 0.01 & 0.642 \\
$30^{\circ}-45^{\circ} \mathrm{S}$ & $y=-0.0007 x+2.110$ & 0.08 & 0.079 \\
$45^{\circ}-60^{\circ} \mathrm{S}$ & $y=0.003 x-5.458$ & 0.58 & $<0.001$ \\
\hline
\end{tabular}

a) In each function, $y$ and $x$ represent $R_{\mathrm{s}}$ and year, respectively.

and soil properties (e.g. SOC and total nitrogen) are recommended, particularly for various biomes in the Southern Hemisphere. Future work should also focus on the partition of soil respiration components.

\section{Conclusions}

The overall $R_{\mathrm{s}}$ rate increased from the colder, drier, and less soil carbon-rich regions to warmer, moister, and more car- 
bon-rich regions. Highest $R_{\mathrm{s}}$ rates appeared in the tropical forest, while the lowest ones were in polar and desert regions. The estimated annual global $R_{\mathrm{s}}$ increased at $\sim 0.04$ $\mathrm{Pg} \mathrm{C} \mathrm{a}^{-1}\left(\sim 0.04 \% \mathrm{a}^{-1}\right)$ from 1970 to 2008 . The annual $R_{\mathrm{s}}$ correlated directly with global temperature anomalies from 1970 to 2008 , suggesting that the interannual variability in temperature was responsible for the interannual variations in predicted global $R_{\mathrm{s}}$. Further investigation indicated that global $R_{\mathrm{s}}$ increased from high-latitude zones to low-latitude zones. Further studies are recommended to explore the relationship between soil respiration and vegetation characters.

This work was supported by the National Basic Research Program of China (2010CB950604), the National Natural Science Foundation of China (41005088 and 41175136) and the Priority Academic Program Development of Jiangsu Higher Education Institutions. We greatly thank the Center for Climatic Research at the University of Delaware, the Independent Foundation of ISRIC-World Soil Information and the Goddard Institute for Space Studies of NASA for providing the global data sets.

1 Reichstein M, Beer C. Soil respiration across scales: The importance of a model-data integration framework for data interpretation. J Plant Nutr Soil Sci, 2008, 171: 344-354

2 Raich J W, Potter C S, Bhagawati D. Interannual variability in global soil respiration, 1980-94. Glob Change Biol, 2002, 8: 800-812

3 Hibbard K A, Law B E, Reichstein M, et al. An analysis of soil respiration across northern hemisphere temperate ecosystems. Biogeochemistry, 2005, 73: 29-70

4 Reichstein M, Rey A, Freibauer A, et al. Modeling temporal and large-scale spatial variability of soil respiration from soil water availability, temperature and vegetation productivity indices. Glob Biogeochem Cycle, 2003, 17: 1104

5 Ryan M G, Law B E. Interpreting, measuring, and modeling soil respiration. Biogeochemistry, 2005, 73: 3-27

6 Bond-Lamberty B, Thomson A. Temperature-associated increases in the global soil respiration record. Nature, 2010, 464: 579-582

7 Bond-Lamberty B, Thomson A. A global database of soil respiration data. Biogeosciences, 2010, 7: 1915-1926

8 Schlesinger W H. Carbon balance in terrestrial detritus. Ann Rev Ecol System, 1977, 8: 51-81

9 Houghton R A, Woodwell G M. Global climatic change. Sci Am, 1989, 260: 36-44

10 Raich J W, Schlesinger W H. The global carbon dioxide flux in soil respiration and its relationship to vegetation and climate. Tellus B, 1992, 44: 81-99

11 Raich J W, Potter C S. Global patterns of carbon dioxide emissions from soils. Glob Biogeochem Cycle, 1995, 9: 23-26

12 Schimel D, Alves D, Enting I, et al. $\mathrm{CO}_{2}$ and the carbon cycle. In: Houghton J T, Meira F L, Callander B A, eds. Climate Change 1995: The Science of Climate Change. Contribution of Working Group I to the Second Assessment Report of the IPCC. Cambridge: Cambridge University Press, 1996. 65-86

13 Chen J, Chen W, Liu J, et al. Annual carbon balance of Canada's forests during 1895-1996. Glob Biogeochem Cycle, 2000, 14: 839849

14 Hayes D J, McGuire A D, Kicklighter D W, et al. Is the northern high-latitude land-based $\mathrm{CO}_{2}$ sink weakening? Glob Biogeochem Cycle, 2011, 25: GB3018

15 Jain A, Yang X, Kheshgi H, et al. Nitrogen attenuation of terrestrial carbon cycle response to global environmental factors. Glob Biogeochem Cycle, 2009, 23: GB4028

16 Allison S D, Wallenstein M D, Bradford M A. Soil-carbon response to warming dependent on microbial physiology. Nat Geosci, 2010, 3 : 336-340

17 Conant R T, Ryan M G, Ågren G I, et al. Temperature and soil or- ganic matter decomposition rates-Synthesis of current knowledge and a way forward. Glob Change Biol, 2011,17: 3392-3404

18 Davidson E A, Samanta S, Caramori S S, et al. The Dual Arrhenius and Michaelis-Menten kinetics model for decomposition of soil organic matter at hourly to seasonal time scales. Glob Change Biol, 2012, 18: 371-384

19 Singh J S, Gupta S R. Plant decomposition and soil respiration in terrestrial ecosystems. Bot Rev, 1977, 43: 449-526

20 Lloyd J, Taylor J A. On the temperature dependence of soil respiration. Funct Ecol, 1994, 8: 315-323

21 Bahn M, Rodeghiero M, Anderson-Dun M, et al. Soil respiration in European grasslands in relation to climate and assimilate supply. Ecosystems, 2008, 11: 1352-1367

22 Kirschbaum M U F. Will changes in soil organic carbon act as a positive or negative feedback on global warming? Biogeochemistry, 2000, 48: 21-51

23 Schlesinger W H, Andrews J A. Soil respiration and the global carbon cycle. Biogeochemistry, 2000, 48: 7-20

24 Bahn M, Janssens I A, Reichstein M, et al. Soil respiration across scales: Towards an integration of patterns and processes. New Phytol, 2010, 186: 292-296

25 Davidson E A, Verchot L V, Cattânio J H, et al. Effects of soil water content on soil respiration in forests and cattle pastures of eastern Amazonia. Biogeochemistry, 2000, 48: 53-69

26 Smith V R. Soil respiration and its determinants on a sub-Antarctic island. Soil Biol Biochem, 2003, 35: 77-91

27 Gough C M, Seiler J R. The influence of environmental, soil carbon, root and stand characteristics on soil $\mathrm{CO}_{2}$ efflux in loblolly pine $(\mathrm{Pi}$ nus taeda L.) plantations located on the South Carolina Coastal Plain. Forest Ecol Manag, 2004, 191: 353-363

28 Rodeghiero M, Cescatti A. Main determinants of forest soil respiration along an elevation/temperature gradient in the Italian Alps. Glob Change Biol, 2005, 11: 1024-1041

29 Chen S T, Huang Y, Zou J W, et al. Modeling interannual variability of global soil respiration from climate and soil properties. Agr Forest Meteorol, 2010, 150: 590-605

30 Shao J. Linear model selection by cross-validation. J Am Statist Assoc, 1993, 88: 486-494

31 Migliavacca M, Reichstein M, Richardson A, et al. Semiempirical modeling of abiotic and biotic factors controlling ecosystem respiration across eddy covariance sites. Glob Change Biol, 2011, 17: 390-409

32 Janssen P H M, Heuberger P S C. Calibration of process oriented models. Ecol Model, 1995, 83: 55-66

33 Hansen J, Ruedy R, Sato M, et al. Global surface temperature change. Rev Geophy, 2010, 48: RG4004

34 Batjes N H. Total carbon and nitrogen in the soils of the world. Europ J Soil Sci, 1996, 47: 151-163

35 Batjes N H. ISRIC-WISE global data set of derived soil properties on a 0.5 by 0.5 degree grid (Version 3.0). Report 2005/08, ISRICWorld Soil Information, Wageningen (with data set), 2005

36 Bond-Lamberty B, Wang C, Gower S T. A global relationship between the heterotrophic and autotrophic components of soil respiration? Glob Change Biol, 2004, 10: 1756-1766

37 Potter C S, Klooster S. Interannual variability in soil trace gas $\left(\mathrm{CO}_{2}\right.$, $\mathrm{N}_{2} \mathrm{O}$, NO) fluxes and analysis of controllers on regional to global scales. Glob Biogeochem Cycle, 1998, 12: 621-635

38 Cramer W, Kicklighter D W, Bondeau A, et al. Comparing global models of terrestrial net primary productivity (NPP): Overview and key results. Glob Change Biol, 1999, 5: 1-15

39 Zhang Y J, Xu M, Chen H, et al. Global pattern of NPP to GPP ratio derived from MODIS data: Effects of ecosystem type, geographical location and climate. Glob Ecol Biogeogr, 2009, 18: 280-290

40 Nemani R R, Keeling C D, Hashimoto H, et al. Climate-driven increases in Global terrestrial net primary production from 1982 to 1999. Science, 2003, 300: 1560-1563

41 Gurney K R, Eckels W J. Regional trends in terrestrial carbon exchange and their seasonal signatures. Tellus B, 2011, 63: 328-339

42 Pan Y D, Birdsey R A, Fang J Y, et al. A large and persistent carbon sink in the world's forests. Science, 2011, 333: 988-993 
43 Myneni R B, Dong J, Tucker C J, et al. A large carbon sink in the woody biomass of Northern forests. Proc Natl Acad Sci USA, 2001, 98: 14784-14789

44 Bahn M, Reichstein M, Davidson E A, et al. Soil respiration at mean annual temperature predicts annual total across vegetation types and biomes. Biogeosciences, 2010, 7: 2147-2157

45 Raich J W, Tufekcioglu A. Vegetation and soil respiration: Correlations and controls. Biogeochemistry, 2000, 48: 71-90

Open Access This article is distributed under the terms of the Creative Commons Attribution License which permits any use, distribution, and reproduction in any medium, provided the original author(s) and source are credited.

\section{Supporting Information}

Figure S1 Temporal variability in maximum annual precipitation $\left(P_{\max }\right)$ within each of the latitude zones. (a), (b), (c), (d), (e), (f), (g), (h), (i) represent the global, $90^{\circ}-75^{\circ} \mathrm{N}, 75^{\circ}-45^{\circ} \mathrm{N}, 45^{\circ}-30^{\circ} \mathrm{N}, 30^{\circ}-10^{\circ} \mathrm{N}, 10^{\circ} \mathrm{N}-10^{\circ} \mathrm{S}, 10^{\circ}-30^{\circ} \mathrm{S}, 30^{\circ}-45^{\circ} \mathrm{S}, 45^{\circ}-60^{\circ} \mathrm{S}$, respectively.

Figure S2 Temporal variability in minimum annual precipitation $\left(P_{\min }\right)$ within each of the latitude zones. (a), (b), (c), (d), (e), (f), (g), (h), (i) represent the global, $90^{\circ}-75^{\circ} \mathrm{N}, 75^{\circ}-45^{\circ} \mathrm{N}, 45^{\circ}-30^{\circ} \mathrm{N}, 30^{\circ}-10^{\circ} \mathrm{N}, 10^{\circ} \mathrm{N}-10^{\circ} \mathrm{S}, 10^{\circ}-30^{\circ} \mathrm{S}, 30^{\circ}-45^{\circ} \mathrm{S}, 45^{\circ}-60^{\circ} \mathrm{S}$, respectively.

Figure S3 Temporal variability in maximum temperature $\left(T_{\max }\right)$ within each of the latitude zones. (a), (b), (c), (d), (e), (f), (g), (h), (i) represent the global, $90^{\circ}-75^{\circ} \mathrm{N}, 75^{\circ}-45^{\circ} \mathrm{N}, 45^{\circ}-30^{\circ} \mathrm{N}, 30^{\circ}-10^{\circ} \mathrm{N}, 10^{\circ} \mathrm{N}-10^{\circ} \mathrm{S}, 10^{\circ}-30^{\circ} \mathrm{S}, 30^{\circ}-45^{\circ} \mathrm{S}, 45^{\circ}-60^{\circ} \mathrm{S}$, respectively.

Figure S4 Temporal variability in minimum temperature $\left(T_{\min }\right)$ within each of the latitude zones. (a), (b), (c), (d), (e), (f), (g), (h), (i) represent the global, $90^{\circ}-75^{\circ} \mathrm{N}, 75^{\circ}-45^{\circ} \mathrm{N}, 45^{\circ}-30^{\circ} \mathrm{N}, 30^{\circ}-10^{\circ}, 10^{\circ} \mathrm{N}-10^{\circ} \mathrm{S}, 10^{\circ}-30^{\circ} \mathrm{S}, 30^{\circ}-45^{\circ} \mathrm{S}, 45^{\circ}-60^{\circ} \mathrm{S}$, respectively.

The supporting information is available online at csb.scichina.com and www.springerlink.com. The supporting materials are published as submitted, without typesetting or editing. The responsibility for scientific accuracy and content remains entirely with the authors. 